\title{
Women and Leadership in Mixed Secondary Schools in Kenya; Do Stakeholder's Attitudes Matter?
}

\author{
ANNE Wangari Mberia (Corresponding author) \\ The Catholic University of Eastern Africa (CUEA), Kenya \\ E-mail: mberianna@yahoo.com
}

Received: October 17, 2016 Accepted: January 24, 2017 Published: March 17, 2017

doi:10.5296/ijssr.v5i1.10157

URL: http://dx.doi.org/10.5296/ijssr.v5i1.10157

\begin{abstract}
Leadership is a process whereby an individual influences a group of individuals to achieve a common goal (Northhouse, 2011). In time and space, women leadership remains a subject talked about but hardly appreciated (Wren, 2013). Among the factors contributing to poor representation of women in leadership is stakeholder's attitude (Coleman, 2005). The study sought to investigate stakeholder's attitudes impeding women teachers' ascension to leadership positions in mixed public secondary schools, focusing in Tharaka South Sub County, Kenya. The study employed descriptive cross-sectional survey design utilizing both qualitative and quantitative methods of data collection. Probability and non-probability sampling techniques were used to arrive at the sample size. Data was collected from women classroom teachers, heads of departments, school principals, education officers, education trade unionists, Parents and Teachers Association officials and School Board of Management officials. Questionnaires, interview guide and focus group discussion guides were used to collect both qualitative and quantitative data. Data analysis was assisted by computer software (Statistical Package for Social Sciences for quantitative data and NVIVO for qualitative data). The study established that education stakeholders have a general negative attitude towards women leadership in schools.
\end{abstract}

Keywords: attitude, leadership, stereotyping

\section{Introduction}

Attitude is an expression of favor or disfavor toward a person, place, thing, or event (Kark \& Eagly, 2010). Attitude about women leaderships are informed by stereotypes and subjective biases resulting from elements of societal stratification (Cheung \& Halpen, 2010). In a stratified society, men view women as less capable of leading. Apart from cultural 
perceptions about women, attitude of the stakeholders in most organizations, which are largely dominated by men, also affect women's quest for leadership. Women are viewed as less capable for leadership, emotionally immature and sometimes considered nagging (Rhode, 2003).

Leadership is important in guiding human actions to conform to certain ideals (Mberia, 2016). The scholar further argues that where proper leadership is exercised, societies experience development in many spheres of life. The concept of leadership comprises the aspects of, people, goals, and influence. According to Mberia (2009) leaders help members to become aware of new possibilities and more significant goals. Fundamentally, leadership can therefore be viewed as an influential action that can be used to achieve goals. Leadership is people driven and the ability to inspire people helps to achieve the set goals of an organization (Daft, Kendrick, \& Vershinina, 2010).

For a long time, leadership has been a dictate of the societal structures. As a result of this while women form more than a half of the population of Kenya, they are disproportionately concentrated in lower level and lower-authoritative leadership position (Davis, 2012; Northouse, 2010). A study conducted by Kipsoi (2010) and Onsongo (2007) pointed out to the locus that women are not well represented in leadership positions in higher educational institutions. Further, leadership has a stronger effect on the attitude of employees towards their jobs (Mberia \& Midigo, 2016). The researchers further posit that there is an increased interest in gender inclusion in appointments and leadership across the world. Traditionally leadership was construed as a masculine enterprise with special challenges and pitfalls for women (Visser, 2011). This notion appears to have persisted to date. Further, Social attitude is an expression of favor or disfavor toward a person, place, thing, or event (Kark \& Eagly, 2010). Social attitudes towards women are acquired tendencies to evaluate women in a specific way and are characterized by positive or negative beliefs, feelings and behaviors.

In Kenya, women constitute a large majority in the teaching profession, but are largely underrepresented in educational administration (Davis, 2012; Northouse, 2010). Despite of the many strategies that have been put into place, the assertion created here is that women teach and men manage. It has been observed that there are equally as many women teachers as men teachers in Tharaka South Sub County $(48.04 \%$ and $51.96 \%$, sub county teachers return). However, what is striking is that out of 17 mixed secondary schools, only one is administered by a woman principal. While this is the case, female students in these schools are in dire need for mentors. This raises the concern as to whether women do not have what it takes to be in leadership or what the issues is that hinders them.

\section{Literature Review}

\subsection{Women Leadership}

Studies have eluded that men and women exhibit differences in leadership styles and abilities. The differences are debated as lying between the concepts of nature and nurture. Studies indicate that women offer desirable leadership styles (Folkman, 2012; Mberia \& Midigo, 2016). Where proportional inclusion of men and women in leadership is achieved, the 
leadership qualities of men blend with that of women to realize optimal leadership results. A study conducted in the U.S. found a positive effect of inclusion of men and women proportionately in top management teams (Dezsò \& Ross, 2012).

Leadership styles refer to a leader's method of providing direction, implementing plans, and motivating people (Wang, Chou, \& Jiang, 2005). As for differences in leadership styles, Eagly (2013) shows that there exist differences in leadership styles and that women showed a bit more democratic or participative leadership styles and a bit less directive/autocratic styles than did their male counterparts. Thus, women's style can be defined as people-based, role modeling and clear expectations and rewards (Eagly \& Carli, 2003).

\subsection{Attitude Towards Women Leadership}

Attitude is an expression of favor or disfavor toward a person, place, thing, or event (Kark \& Eagly, 2010). Attitude about women leaderships are informed by stereotypes and subjective biases resulting from elements of societal stratification (Cheung \& Halpen, 2010). In a stratified society, men view women as less capable of leading. Kark, Waismel-Manor and Shamir (2012) noted that if the society is biased against women, women's ability to see themselves as suitable for leadership is but a mirage. Coleman (2011) also noted that gendered attitude play a crucial role in women career progression and strongly support women's child care and domestic responsibility whereas men have been give the role of breadwinner (Bushra, 2014). Mirza and Jabeen (2012) also noted that women are particularly less likely to acquire skills, training and competencies necessary for professional advancement and management position given the general attitude that is held against them. This is confirmed by Shah and Shah (2012) who noted that women were not given opportunities to participate outside their homes and hence had less access to senior management positions is governed by societal belief systems.

The attitude about women leadership is acquired through socialization. In most societies, men are socialized to be leaders while women to accept male leadership. While school leadership presents a social environment epitomizing higher levels of civilization, the cultural stereotyping, as embedded in traditions, greatly influence the attitude held about women in leadership. A study conducted by Osumbah (2011) revealed that women are perceived to be less assertive, reluctant to hold power, lack self-confidence, are unwilling to play the game or work the system, do not apply for jobs and even when in a job, do not apply for line positions. On the other hand, Taylor and Hood (2011); Brinia (2012) and Elesser and Lever (2011), have shown that women leaders, as compared with men, are perceived as more intelligent, better decision-makers, more hard-working, ambitious, confident, having better communication skills, and being honest and supportive. Mann (2009) argues that men are considered to be more forceful, assertive, aggressive, confident, independent, rational and task-oriented, whereas women are perceived as more nurturing, emotional, considerate, submissive, affectionate, indecisive and people oriented. As a result there exist different expectations and attitudes to women and men and to their management skills.

Hilary Rodham Clinton, former Secretary of State of the USA once said; 'The status of the world's women is not only a matter of morality and justice. It is also a political, economic 
and social imperative: women are free to develop their talents and contribute fully to their societies, everyone benefits". She went on to say"...I want to see more women compete for the highest positions in their countries...we have to break down these attitudes that pigeon-hole and stereotype people, like, what does a leader look like...well, a leader looks like somebody who is a man"(U.S.A. Government, 2001). She would not be more correct because in many societies, and particularly African societies, the leadership role has been for a long time the preserve of men.

Women leadership also suffer the challenge of perceptions. According to Fiske and Taylor (2013), perception is a process of creating internal representation of the external world. Perception of what constitutes "good" or appropriate leadership behaviours has been socially scribed traditional stereotypes that favour men as having better leadership qualifications. When leadership occurs, it takes one or more person to engage with others in such a way that leaders and followers raise one another to higher levels of motivation and morality. Traditionally teaching has been seen as complementary to a women's role as wife and mother. Management on the other hand is seen as contradictory to this role (Dalton, 2013). Thus, is it acceptable to teach and be a mother, but the moment you become a manager you are no longer a good mother.

The constraints arise from the socially defined expectations that women will be responsible for domestic matters including childcare. From a study conducted by Guendouzi (2006), it also appears that women will rather wait till they have reached their career objectives before starting a family or they will wait till their children are grown up before applying for promotion posts, thus making their climbing up the promotion ladder shorter. Additionally, literature indicate that women tend to modify their career aspirations due to domestic responsibilities and that later in their lives after they have raised their children, they become ambitious and seek promotion posts. This is not done because they are incompetent but because it puts less stress on themselves and their families. (Frome, Alfeld, Eccles, \& Barber, 2006; Wajcman, 2013; Sirianni \& Negrey, 2000).

Beinomugisha, Kamya and Said (2014) indicated that one of the perceptions that exists about women in management is that they are unstable workers. Due to the pressure society puts on these managers they are forced to obtain success at any cost. They sometimes have to be aggressive to be able to survive in the "muscular" world of management. To some people this can cause them to form the perception that women are unstable workers (Barker, 2015). In another study conducted by Prime, Carter and Welbourne (2009), men in management positions perceived women to be less capable for leadership because of their social expectations. Further, Catalyst et al. (2007) concluded that women are perceived as too soft or too tough but never just right, that women leaders face higher standards and lower rewards than men leaders and that women leaders are perceived as competent or liked, but rarely both. It is worth noting here that from an early age, women are socialised to be soft while on the other hand toughness is expected from men yet when it comes to leadership men are expected to remain tough while the same society expects that women have to be soft at the social realm but tough at the leadership levels. This appears to create a contradiction as women should be allowed to remain who they are even at leadership levels and not be measured on "toughness" 
but on ability to deliver on their mandate.

Chodorow (2001) argues that girls experience the concept 'femininity' in terms of their relationship with men, and thus accept that their primary task is to embrace and care for men. Chodorow further argue that one of the most important reasons why women do not apply for promotional posts is that they and men believe that women lose their femininity the moment they become a manager. On the other hand, people consider women as poor leaders if they act 'feminine', and again, if they act masculine are seen as deviants and condemned as 'unfeminine' (Oakley, 2015). Robbins, Judge, Millett and Boyle, (2013) agrees that when women first started to pour into the labour force, they tried to be more like men by wearing power suits and picking up golf clubs. According to Robbins et al. (2011), this has changed, people continue to realise that if one wants a great manager, they one must hire a qualified person regardless of their gender. There is also the feeling that women managers bring a feminine touch into their job environment, but that the environment may not be ready to embrace them for who they are (Sandberg, 2013).

In her research, Chisholm (2001) indicated that every woman that she interviewed had problems having her authority accepted once she had been appointed. Simpson, (2004) found that men had discomfort working under female managers. Men also have the tendency to exhibit hostility in dealing with female managers and that these managers had to work harder for men to "hear" them. Men are also afraid of the "tears" of women when confronting them. This fear of tears keeps men from giving corrective feedback to women to enable them to be better leaders. Men feel that they are in a no-win position: If he treats a woman as he treats a man he may be accused of being harsh. If he gives her too much attention he can be accused of sexual interest. Other studies also conducted on challenges facing women leadership also indicate that although the teaching environment is made up of both men and women, men in management are acceptable, but women in management experience problems not only from male employees, but from female employees as well (Seoloane, 2012; Nias, 2002).

\section{Methodology}

The study adopted cross sectional survey design and used mixed methods of data collection and analyses. The target population included all principals, women teachers, heads of department, education officers, chairpersons of school Board of Management, chairpersons of Parents Teachers Association and education trade unionists. Both simple and stratified random sampling was used to come up with the sample population. A sample of 106 respondents participated in the study. Both qualitative and quantitative data were collected. Quantitative data was analyzed using SPSS (V.22) while qualitative data was analyzed using NVIVO. Results are presented in tables and verbatim.

\section{Findings and Discussions}

Attitude about women leaderships are informed by stereotypes and subjective biases resulting from elements of societal stratification (Cheung \& Halpen, 2010). In a stratified society, men view women as less capable of leading (Kark, Waismel-Manor, \& Shamir, 2012). Stakeholder attitude towards women leadership was measured against 6 leadership attributes including 
confidence, flexibility in decision making, competency in administration, approachability honesty in financial management and peace building and conflict avoidance. The findings from the quantitative data were triangulated with the verbatim obtained from the qualitative data.

\subsection{Confidence to Lead}

Table 1 represents the stakeholder's attitude towards women's confidence to lead.

Table 1. Confidence to lead

\begin{tabular}{lllllll}
\hline Respondents & $\begin{array}{l}\text { Strongly } \\
\text { agree }\end{array}$ & Agree & Neutral & Disagree & $\begin{array}{l}\text { Strongly } \\
\text { Disagree }\end{array}$ & Total \\
\hline Women Teachers & $17(6.7 \%)$ & $197(77.3 \%)$ & $13(5.1 \%)$ & $28(11.0 \%)$ & $0(0.0 \%)$ & $\mathbf{2 5 5}$ \\
Education Officers & $1(10.0 \%)$ & $8(80.0 \%)$ & $1(10.0 \%)$ & $0(0.0 \%)$ & $0(0.0 \%)$ & $\mathbf{1 0}$ \\
Trade Unionists & $1(50.0 \%)$ & $1(50.0 \%)$ & $0(0.0 \%)$ & $0(0.0 \%)$ & $0(0.0 \%)$ & $\mathbf{2}$ \\
School Principals & $4(11.8 \%)$ & $15(44.1 \%)$ & $6(17.6 \%)$ & $7(20.6 \%)$ & $2(5.9 \%)$ & $\mathbf{3 4}$ \\
\hline
\end{tabular}

Majority of the women teachers (77.3\%) agreed that female principals were confident while only $5.0 \%$ of them being neutral. Most of the education officers, $80 \%$ agreed that women leaders were confident. Of the school principals sampled, $44.1 \%$ agreed with the statement that women were confident to lead. The trade unionists were all in agreement that women have the confidence to lead. This implies that women teachers are viewed as confident to lead. Similar findings also emerged during the qualitative interviews. This finding contradicts an earlier study conducted by Osumbah (2011) where it was noted that women were not assertive enough, did not want power, lacked self-confidence, were unwilling to play the game or work the system and that they did not apply for jobs and even when in a job, they did not apply for higher positions. The results of this study also disagree with Fitzgerald (2013) who stated that many women do not have the self-confidence or lack the ambition to pursue leadership positions. The deviation in perception about women's confidence in leadership from the earlier studies indicates a possibility of change in perception.

\subsection{Flexibility in Decision Making}

The stakeholder's attitude towards women leader's flexibility in decision making were as represented in table 2 below.

Table 2. Flexibility in decision making

\begin{tabular}{llllllr}
\hline Respondents & $\begin{array}{l}\text { Strongly } \\
\text { agree }\end{array}$ & Agree & Neutral & Disagree & $\begin{array}{l}\text { Strongly } \\
\text { Disagree }\end{array}$ & Total \\
\hline Women Teachers & $13(5.1 \%)$ & $61(23.9 \%)$ & $9(3.5 \%)$ & $134(52.5 \%)$ & $38(14.9 \%)$ & $\mathbf{2 5 5}$ \\
Education Officers & $0(0.0 \%)$ & $1(10 \%)$ & $2(20 \%)$ & $7(70 \%)$ & $0(0.0 \%)$ & $\mathbf{1 0}$ \\
Trade Unionists & $0(0.0 \%)$ & $0(0.0 \%)$ & $0(0.0 \%)$ & $2(100 \%)$ & $0(0.0 \%)$ & $\mathbf{2}$ \\
School Principals & $2(5.9 \%)$ & $10(29.4 \%)$ & $7(20.6 \%)$ & $12(35.3 \%)$ & $2(5.9 \%)$ & $\mathbf{3 4}$ \\
\hline
\end{tabular}


Majority of the women teachers $(52.5 \%)$ disagreed that women leaders are flexible in decision making. This was also true of $70 \%$ of the education officers. About $35.3 \%$ of the school principals also disagreed that women were flexible in decision making. In a focus group discussion with the heads of departments, it emerged that

In most cases, women leaders do not consult when making decisions...maybe they fear...others may think that they are consulting because they don't know (Focus Group Discussion, $6^{\text {th }}$ March 2015)

This finding shows that women leaders are perceived to be not flexible in decision making. The results agrees with the findings of Ertac (2015) where women were found to have a lower acceptance in taking group decision and at the same time more unwilling to accommodate contrary opinions. In another study conducted by Missioura (2014), on women leadership in Malawi the scholar noted that women principals took time to make good decisions. They tended to weight the positive and negative side of the different options, considering the alternative and made the choice on the best option. This could be explained as a result of the scrutiny that women leaders have to contend with. According to Oakley (2000), when women become one of the few that have reached the top, they will be watched closer, and subjected to greater scrutiny resulting in risk aversion (Oakley, 2000). Women therefore have to ensure that they make decisions that they have to identify with. A woman leader therefore lives in fear of wrong decisions and thus would rather make her own decision and stand by it. It is also possible that because of the scrutiny, suspicions exist between women leaders and their staff hence making the woman protective of her decisions.

\subsection{Competency in Administration}

The attitude of the respondents on the competency of women in administration is as presented in table 3 below.

Table 3. Competency in administration

They are competent administrators

\begin{tabular}{lllllll}
\hline Respondents & Strongly agree & Agree & Neutral & Disagree & $\begin{array}{l}\text { Strongly } \\
\text { Disagree }\end{array}$ & $\begin{array}{c}\text { Total } \\
\text { Women Teachers }\end{array}$ \\
Education Officers & $133(52.2 \%)$ & $68(26.7 \%)$ & $15(5.9 \%)$ & $24(9.4 \%)$ & $15(5.9 \%)$ & $\mathbf{2 5 5}$ \\
Trade Unionists & $5(50 \%)$ & $3(30 \%)$ & $1(10 \%)$ & $1(10 \%)$ & $0(0.0 \%)$ & $\mathbf{1 0}$ \\
School Principals & $(0.0 \%)$ & $2(100 \%)$ & $0(0.0 \%)$ & $0(0.0 \%)$ & $0(0.0 \%)$ & $\mathbf{2}$ \\
\hline
\end{tabular}

Slightly above half $(52.2 \%)$ of the women teachers strongly agreed that women principals were competent administrators and were self-disciplined, while $26.7 \%$ of them agreed. Half of the education offices $(50.0 \%)$ agreed that women principals were competent administrators. All the trade unionists and $57.1 \%$ of the school principals and all the trade unionists also agreed that women leaders are competent administrators. One of the education officers noted that they had worked with competent women principals within the county and felt that they were significantly disciplined especially in such areas as time, payments, parents' matters, 
students and even the staff in their schools. The relationship between the principals the school community was also said to be cordial because of their self-discipline. This implies that women leaders are perceived to be competent administrators. The findings therefore concur with an earlier study conducted by Kirkpatick (1991) where it was concluded that women leadership was more democratic, honest and focused to organizational goals. In another study conducted by Catalyst, Inc. (2007) women were perceived as too soft or too tough but never just right, that they face higher standards and lower rewards than men leaders and that they are perceived as competent or liked, but rarely both. This therefore implies that while the positive leadership traits of women are appreciated, they are rarely given chance by the society to lead.

\subsection{Approachability}

The attitude of stakeholders about women leaders' approachability was also investigated and the results were as shown in table 4 .

Table 4. Approachability

They are approachable

\begin{tabular}{llllllr}
\hline Respondents & Strongly agree & Agree & Neutral & Disagree & Strongly Disagree & Total \\
\hline Women Teachers & $35(13.7 \%)$ & $129(50.6 \%)$ & $7(2.7 \%)$ & $55(21.6 \%)$ & $28(11.0 \%)$ & $\mathbf{2 2 5}$ \\
Education Officers & $3(30 \%)$ & $6(10 \%)$ & $1(10 \%)$ & $0(50.0 \%)$ & $0(0.0 \%)$ & $\mathbf{1 0}$ \\
Trade Unionists & $0(0.0 \%)$ & $1(50 \%)$ & $0(0.0 \%)$ & $1(50 \%)$ & $0(0.0 \%)$ & $\mathbf{2}$ \\
School Principals & $2(5.9 \%)$ & $7(21.4 \%)$ & $15(42.9 \%)$ & $5(13.7 \%)$ & $5(14.9 \%)$ & $\mathbf{3 4}$ \\
\hline
\end{tabular}

About $50.6 \%$ of the women teachers agreed that women leaders were approachable. About $50 \%$ of the education officers indicated that women principals were not approachable. Of the school principals sampled, $42.9 \%$ were neutral while $21.4 \%$ agreed that women principals are approachable. In a key informant interview, a school board of management members noted that women leaders could not work well with the school community. Another education officer further noted that although women were calm and friendly when dealing with members of the school community, the community looked at them as not approachable. It also emerged from the interviews with the education officers that women principals were approachable in many of the activities but sometimes were very rigid especially in issues they did not want the sponsor to interfere with. About $42.9 \%$ of the principals were neutral while $28.6 \%$ disagreed. These findings indicate that women leaders are viewed to be less approachable.

\subsection{Honesty in Financial Management}

As an attribute of good leadership, leaders are expected to exhibit honesty in financial management. The attitude of stakeholders on financial management of women leaders are as presented in table 5 below, 
Table 5. Honesty in financial management

\begin{tabular}{llllllr}
\multicolumn{7}{c}{ They are honest } \\
\hline Respondents & Strongly agree & Agree & Neutral & Disagree & Strongly Disagree & Total \\
\hline Women Teachers & $138(54.1 \%)$ & $79(31.0 \%)$ & $14(5.5 \%)$ & $10(3.9 \%)$ & $12(4.7 \%)$ & $\mathbf{2 5 5}$ \\
Education Officers & $4(40 \%)$ & $3(30 \%)$ & $2(20 \%)$ & $1(10 \%)$ & $0(0.0 \%)$ & $\mathbf{1 0}$ \\
Trade Unionists & $0(0.0 \%)$ & $1(50 \%)$ & $1(50 \%)$ & $0(0.0 \%)$ & $0(0.0 \%)$ & $\mathbf{2}$ \\
School Principals & $9(26.5 \%)$ & $16(47.1 \%)$ & $5(14.7 \%)$ & $2(5.9 \%)$ & $2(5.9 \%)$ & $\mathbf{3 4}$ \\
\hline
\end{tabular}

Slightly above half $(54.1 \%)$ of the women teachers, $40 \%$ of the education officers strongly agreed that women principals were honest. About $50 \%$ of the trade unionists and $47.1 \%$ of the school principals respectively also agreed. Further, about $40 \%$ of the education officers agreed that women principals were peace makers. In an interview with the PTAs and the $\mathrm{BOM}$, it emerged that women principals had confidence in their work, not flexible in decision making, are honest, are peace makers and competent decision makers. One of the education officers noted that,

... out of the many cases I have received from the school in the sub-county none had been brought from the schools led by women principals...they are peaceful and in most cases avoid conflicts (Key Informant Interview, $4^{\text {th }}$ March 2015).

From these findings, it is evident that women teachers, education officers, principals and other education stake holders perceive women to be possessing positive leadership qualities including honesty and conflict resolution. These findings contrast with a study conducted by Chisholm (2001) which found out that most education stakeholders found it difficult to accept authority of women leaders and that this was influenced by their perceptions about the women leaders. The results, however, concur with those of Schmidt and Mestry (2015) who noted that women principals were peace makers and avoid conflicts. Based on the experience of women as nurturers and caregivers, it can be concluded that women principals are able to use their problem solving skills gained in the society in the context of school administration for conflict management.

\subsection{Peacemaking and Conflict Avoidance}

Table 6 represents the attitude about women leader's leadership attribute of peace making and conflict avoidance.

Table 6. Peacemaking and conflict avoidance

They are peace-makers and avoid conflicts

\begin{tabular}{llllllr}
\hline Respondents & Strongly agree & Agree & Neutral & Disagree & Strongly Disagree & Total \\
\hline Women Teachers & $55(24.4 \%)$ & $142(63.1 \%)$ & $30(13.3 \%)$ & $20(8.9 \%)$ & $8(3.6 \%)$ & $\mathbf{2 5 5}$ \\
Education Officers & $4(40 \%)$ & $5(50 \%)$ & $1(10 \%)$ & $0(0.0 \%)$ & $0(0.0 \%)$ & $\mathbf{1 0}$ \\
Trade Unionists & $0(0.0 \%)$ & $2(100 \%)$ & $0(0.0 \%)$ & $0(0.0 \%)$ & $0(0.0 \%)$ & $\mathbf{2}$ \\
School Principals & $10(29.4 \%)$ & $14(41.2 \%)$ & $2(5.9 \%)$ & $6(17.6 \%)$ & $2(5.9 \%)$ & $\mathbf{3 4}$ \\
\hline
\end{tabular}


Above half, $63.1 \%$ of the women teachers agreed that women leaders were peace makers and avoided conflict. The education officers also affirmed this perception with $50 \%$ and $40 \%$ agreeing and strongly agreeing respectively that women leaders were peacemaking and avoided conflicts. A majority, $41.2 \%$ of the principals also affirmed the same. In an interview with the PTAs and the BOM, it emerged that women leaders are peace makers. One of the education officers noted that

... out of the many cases I have received from the school in the sub-county none had been brought from the schools led by women principals...they are peaceful and in most cases avoid conflicts (Key Informant Interview, $4^{\text {th }}$ March 2015).

\section{Conclusion}

The study concludes that education stakeholders have mixed attitude towards women leadership. Women leaders are perceived to be possessing positive leadership qualities including honesty and conflict resolution, that they are peace makers and competent decision makers. On the contrary, respondents were of the view that women are not flexible in decision are more unwilling to accommodate contrary opinions, and that they are not approachable.

\section{Contributions of the Study}

The study was conducted in the Rural set ups of Tharaka South Sub-County in Kenya where similar studies are rare and therefore aimed at filling knowledge gap regarding the study topic in the area. Further, the study employed mixed methodologies and therefore through triangulation, results were authenticated. The study also included education stakeholders outside the normal school environment with an aim of obtaining deeper understanding of the topic at hand.

\section{Limitations of the Study}

The present study investigated the attitude of education stakeholders on women leadership. It was limited to oral reports from the participants. The study was also limited to Tharaka South Sub-County and is therefore not generalizable to other areas.

\section{Suggestions for Future Research}

The study established that women's participation in leadership is still viewed with mixed reactions. Since politics play a fundamental role in formulation of policies and advocacy, the researcher suggests a need for a study that will interview the politicians in the region in order to understand their view on women and leadership of mixed secondary schools.

Additionally, there is a need to conduct more research (both longitudinal and ethnographic) about women leadership and disseminate such information to the wider public using methods which can be understood by all. 


\section{Acknowledgement}

This study was conducted in Tharaka South Sub-County, Kenya. The researcher appreciates all the respondents and the education administration in the Sub-County. The researcher also appreciates the technical support from Prof. Mary Getui and Sr. Dr. Elizabeth Nduku of the Catholic University of Eastern Africa (CUEA).

\section{References}

Beinomugisha, P., Kamya, E., \& Said, B. (2014). Ability to Deliver and Advancement of Women in Academic and Administrative Positions in Public Universities in Central Uganda.

Brinia, V. (2012). Men vs women; educational leadership in primary schools in Greece: an empirical study. International Journal of Educational Management, 26(2), 175-191.

Bushra, I. (2014). Influence of familial, societal, organizational and personal factors on women's career advancement to senior management position in the universities of Pakistan. University of London. Doctor of Philosophy Thesis

Mann, F. M. (2009). Entrepreneurial women and men: two different species? Small Business Economics, 16(3), 167-175.

Catalyst. (2012). Quick Take: Women in Management, Global Comparison. New York: Catalyst, January, 2016. Retrieved from http://www.catalyst.org/knowledge/women_management-global-comparison

Cheung, F., \& Halpern, D. (2010). Women at the top: Powerful leaders define success as work family in a culture of gender. American Psychologist, 65(3), 182-193.

Chisholm, L. (2001). Gender and leadership in South African educational administration. Gender and education, 13(4), 387-399.

Coleman, M. (2005). Gender and Secondary School Leadership. International Studies in Educational Administration, 33(2).

Coleman, M., \& Glover, D. (2010). Educational Leadership And Management: Developing Insights And Skills: Developing Insights and Skills. McGraw-Hill Education (UK).

Cowling, M., \& Taylor, M. (2001). Entrepreneurial women and men: two different species?. Small Business Economics, 16(3), 167-175.

Daft, R. L., Kendrick M., \&Vershinina, N. (2010). Management. Cengage Learning EMEA.

Dalton, M. (2013). Men who manage: Fusions of feeling and theory in administration. Transaction Publishers.

Davis, K. (2008). Intersectionality as buzzword A sociology of science perspective on what makes a feminist theory successful. Feminist theory, 9(1), 67-85.

Dezsö, C. L., \& Ross, D. G. (2012). Does female representation in top management improve firm performance? A panel data investigation. Strategic Management Journal, 33(9), 
1072-1089.

Elsesser, K. M., \& Lever, J. (2011). Does gender bias against female leaders persist? Quantitative and qualitative data from a large-scale survey. Human Relations, 64(12), 1555-1578.

Ertas, N. (2015). Turnover intentions and work motivations of millennial employees in federal service. Public Personnel Management, 0091026015588193.

Fiske, S. T., \& Taylor, S. E. (2013). Social cognition: From brains to culture. Sage.

Folkman, Z. (2012). A study in leadership: Women do it better than men. Real Women, Real Leaders: Surviving and Succeeding in the Business World, 165-169.

Frome, P. M., Alfeld, C. J., Eccles, J. S., \& Barber, B. L. (2006). Why don't they want a male-dominated job? An investigation of young women who changed their occupational aspirations. Educational Research and Evaluation, 12(4), 359-372.

Guendouzi, J. (2006). "The guilt thing": Balancing domestic and professional roles. Journal of Marriage and Family, 68(4), 901-909.

Kark, R., \& Eagly, A. H. (2010). Gender and leadership: Negotiating the labyrinth. In Handbook of gender research in psychology (pp. 443-468). Springer New York.

Kark, R., Waismel-Manor, R., \& Shamir, B. (2012). Does valuing androgyny and femininity lead to a female advantage? The relationship between gender-role, transformational leadership and identification. The Leadership Quarterly, 23(3), 620-640.

Kipsoi, E. J. (2010). Women Participation in University Leadership: The Case of Selected Private and public Universities in Kenya. Unpublished PhD Thesis Kenyatta University.

Kirkpatick, S. A., \& Locke, E. A. (1991). Leadership: do traits matter?. The executive, 5(2), 48-60.

Levenson, A. R., Van der Stede, W. A., \& Cohen, S. G. (2006). Measuring the relationship between managerial competencies and performance. Journal of Management, 32(3), 360-380.

Mberia, A., \& Midigo, R. (2016). Leadership styles and employee job satisfaction in public service in Kenya; understanding the gender factor International. Journal of Academic Research and Reflection, 4(6), 2016.

Mberia, A., \& Midigo, R. (2016). Leadership; relating employee satisfaction to leadership styles and gender in Kenya: Manuscript submitted for publication.

Mberia, A. (2009) challenges facing head teacher's in administration of inclusive education in public primary schools in Nairobi west district, Kenya, University of Nairobi.

Mirza, A. M. B., \& Jabeen, N. (2011). Gender Stereotypes and Women in Management The Case of Banking Sector of Pakistan. South Asian Studies, 26(2), 259.

Mirza, A. M. B., \& Jabeen, N. (2011). Gender Stereotypes and Women in Management The 
Case of Banking Sector of Pakistan. South Asian Studies, 26(2), 259.

Nias, J. (2002). Primary teachers talking: A study of teaching as work. Routledge.

Northouse, P. G. (2011). Introduction to leadership: Concepts and practice. Sage Publications.

Oakley, A. (2015). Sex, gender and society. Ashgate Publishing, Ltd.

Oakley, J. G. (2000). Gender-based barriers to senior management positions: Understanding the scarcity of female CEOs. Journal of business ethics, 27(4), 321-334.

Onsongo, J. (2007). The growth of private universities in Kenya: Implications for gender equity in higher education. Journal of Higher Education in Africa, 5(2-3), 111-133.

Osumbah, B. A. (2011). Representation of women in top educational management and leadership positions: a case of ministry of education headquarters, Nairobi-Kenya (Doctoral dissertation).

Prime, J. L., Carter, N. M., \& Welbourne, T. M. (2009). Women "take care," men "take charge": Managers' stereotypic perceptions of women and men leaders. The Psychologist-Manager Journal, 12(1), 25-49.

Rhode, D. L. (2003). The difference" difference" makes: Women and leadership. Stanford University Press.

Robbins, S., Judge, T. A., Millett, B., \& Boyle, M. (2013). Organisational behaviour: Pearson Higher Education AU.

Sandberg, S. (2013). Lean in: Women, work and the will to lead. New York.

Schmidt, M., \& Mestry, R. (2015). The Experiences of Female Principals in the Gauteng Province. American Journal of Educational Research, 3(7), 813-821.

Seoloane, E. M. (2012). Cultural factors as an aspect of culturally sensitive feedback: implication for the management of teacher competence (Doctoral dissertation).

Shah, S., \& Shah, U. (2012). Women, educational leadership and societal culture. Education Sciences, 2(1), 33-44.

Simpson, R. (2004). Masculinity at work the experiences of men in female dominated occupations. Work, Employment \& Society, 18(2), 349-368.

Sirianni, C., \& Negrey, C. (2000). Working time as gendered time. Feminist Economics, 6(1), 59-76.

Taylor, S. N., \& Hood, J. N. (2011). It may not be what you think: Gender differences in predicting emotional and social competence. Human Relations, 64(5), 627-652.

Ulrich, D., Zenger, J., \& Smallwood, N. (2013). Results-based leadership. Boston: Harvard Business Press.

Visser, M. (2011). The Female Leadership Paradox: Power, Performance and Promotion. 
New York: Palgrave Macmillan.

Wajcman, J. (2013). Managing like a man: Women and men in corporate management. John Wiley \& Sons.

Wang, E., Chou, H. W., \& Jiang, J. (2005). The impacts of charismatic leadership style on team cohesiveness and overall performance during ERP implementation. International Journal of Project Management, 23(3), 173-180.

Wickramasinghe, V., \& De Zoyza, N. (2009). A comparative analysis of managerial competency needs across areas of functional specialization. Journal of Management Development, 28(4), 344-360.

Wren, J. T. (2013). The leader's companion: Insights on leadership through the ages. Simon and Schuster.

\section{Copyright Disclaimer}

Copyright for this article is retained by the author(s), with first publication rights granted to the journal.

This is an open-access article distributed under the terms and conditions of the Creative Commons Attribution license (http://creativecommons.org/licenses/by/3.0/). 